\title{
Lexical integration: Sequential effects of syntactic and semantic information
}

\author{
ANGELA D. FRIEDERICI, KARSTEN STEINHAUER, and STEFAN FRISCH \\ Max Planck Institute of Cognitive Neuroscience, Leipzig, Germany
}

\begin{abstract}
Both semantic and syntactic context constraints can influence word processing at the level of lexical integration. In event-related brain potentials (ERPs), semantic integration is reflected by a negativity around $400 \mathrm{msec}(\mathrm{N} 400)$, whereas phrase structure assignment and syntactic integration are assumed to be reflected by an early left anterior negativity and a late positivity (P600), respectively. An ERP study is presented in which participants read different types of sentences whose terminal verb was either congruent with the preceding context or incongruent due to a phrase structure violation, a semantic violation, or both. The main finding was that only the pure semantic violation condition, but not the combined semantic and syntactic violation condition, elicited a large N400. The two conditions containing phrase structure violations were predominantly characterized by a P600. Both semantic violation conditions, moreover, displayed a late negativity around $700 \mathrm{msec}$ that overlapped with the $\mathrm{P} 600$ in the double violation condition. The absence of an N400 effect for elements that are syntactically as well as semantically incongruent with prior context suggests an early influence of phrase structure information on processes of lexical-semantic integration. The present data are discussed in comparison to previous ERP findings, and a new view of lexical integration processes is proposed.
\end{abstract}

A central mechanism underlying language comprehension is the process of word recognition. This process is assumed to consist of three basic subprocesses: lexical access, lexical selection, and lexical integration (Frauenfelder \& Tyler, 1987; Marslen-Wilson, 1987, 1989). During lexical access, the initial input activates a subset of compatible entries in the mental lexicon, the best candidate of which is then selected in the second step (Zwitserlood, 1989). Finally, the selected lexical item is integrated into a higher order representation as specified by the semantic and syntactic constraints of the current context.

\section{Semantic Context Effects}

Semantic context effects in word recognition are often discussed in terms of semantic priming. Semantic priming refers to the finding that word recognition is typically faster when the target word (e.g., doctor) is preceded by a semantically related prime word (e.g., nurse; Meyer \& Schvaneveldt, 1971). In a recent review of a large number of behavioral studies, Neely suggested that three different mechanisms contribute to the complex pattern of semantic priming effects (Neely, 1991; Neely \& Keefe, 1989). The first mechanism is conceived as an automatic spread-

We thank Sonja Kotz and Clare Foa as well as five anonymous reviewers for helpful comments on earlier versions of this paper. The work reported was supported by the Leibniz Science Prize, awarded to A.D.F., and by a grant from the German Research Foundation (DFG FR 519/12-2). Correspondence should be addressed to A. D. Friederici, Max Planck Institute of Cognitive Neuroscience, P.O. Box 500355,04303 Leipzig, Germany (e-mail: angelafr@cns.mpg.de). ing of activation within the network of semantic memory where nodes of semantically related words are strongly linked to one another (Anderson, 1983; Collins \& Loftus, 1975). According to the second proposed mechanism, expectancy-based priming, the prime word is used to generate an expectancy set consisting of potential targets. If the actual target word is included in this set, it can be recognized more easily (see, e.g., Becker, 1980, 1985; Posner \& Snyder, 1975). The third and quite heterogeneous group of mechanisms can be characterized as postlexical semantic checking or integration mechanisms, which affect word processing only after the lexical entry has already been accessed (Foss \& Speer, 1991; Neely \& Keefe, 1989; Norris, 1986; Ratcliff \& McKoon, 1988).

\section{Syntactic Context Effects}

In sentence contexts, word integration has to meet syntactic constraints in addition to semantic constraints. Similar to semantic priming effects, syntactic congruency facilitates word processing, whereas incongruency inhibits it (Deutsch \& Bentin, 1994; Stanovich \& West, 1983; West \& Stanovich, 1986; Wright \& Garrett, 1984). Since syntactic priming effects are more likely to be observed in a lexical decision task than in a pronunciation task (Seidenberg, Waters, Sanders, \& Langer, 1984), most proposals accounting for syntactic priming identify not prelexical but rather postlexical processes such as response interference (West \& Stanovich, 1986), attentional shifts (Deutsch \& Bentin, 1994), or rechecking mechanisms as the critical locus.

Taken as a whole, lexical integration must evaluate both semantic and syntactic properties of a word in their respec- 
tive relations to the preceding context. It is not entirely clear, however, whether the underlying operations act independently and in parallel or whether they interact as lexical integration proceeds. O'Seaghdha (1989) found a semantic priming effect in syntactically congruent contexts, but not when prime and target were presented in a scrambled word context. Schriefers, Friederici, and Rose (1998) reported that even violations of local syntactic constraints (i.e., article-noun gender disagreement) reduce the semantic priming effect. In contrast, the additive effects of syntax and semantics observed by Gunter, Stowe, and Mulder (1997) point to parallel processing mechanisms.

Thus, although syntax seems to influence the semantic aspects of lexical integration to some extent, the timing and mechanisms are still controversial, particularly concerning the earliest stages. Interactive models of word recognition (Elman \& McClelland, 1984; Marslen-Wilson \& Tyler, 1980; McClelland \& Rumelhart, 1981) predict an interaction of the different aspects to be already present in the initial phase. Modular models of word recognition, in contrast, claim lexical autonomy for the initial phase of lexical access (Swinney, 1979; Tanenhaus, Carlson, \& Seidenberg, 1985). With respect to subsequent phases, parallel models predict an interaction only after semantic and syntactic aspects have been processed independently and the two types of information are fed into a process responsible for further interpretation. Serial models, in contrast, predict a primacy of specific syntactic processes and thus allow for their influence on semantic processes, but not vice versa. Such a primacy in the processing of syntactic aspects could be due to either a temporal difference in the lexical availability of the different types of relevant information (Levelt, 1989) or the temporal difference in the use of this information during lexical integration in sentence contexts. Serial models (e.g., Frazier, 1987; Friederici, 1995; Gorrell, 1995; Mitchell, 1989) hold that at least syntactic word category information is used prior to semantic information in order to generate an initial syntactic representation-that is, the phrase structure. ${ }^{1}$ This notion makes the strong prediction that phrase structure violations (i.e., word category violations) should be able to influence later stages of sentence processing without being susceptible to other information themselves. To date, the vast majority of available data from behavioral experiments investigating the interaction of syntactic and semantic aspects does not seem to allow a final conclusion concerning the nature of the interaction because the time course of the syntactic and semantic processes and their possible interaction remains unspecified.

The registration of event-related brain potentials (ERPs) may help to specify the temporal course of lexical processing and of the integration of syntactic and semantic information in particular. ERPs are being increasingly used to investigate different aspects of language processing. The technique allows on-line monitoring of the brain's activity with a millisecond-by-millisecond resolution and thus allows the evaluation of the temporal structure and coordination of different subprocesses. Furthermore, un- like reaction time (RT) measures, ERPs provide qualitatively different correlates of semantic and syntactic processes. It has been established for more than a decade that semantic aspects of language processing are primarily correlated with a negative-going waveform elicited around $400 \mathrm{msec}$ after word onset-namely, the N400 component (for a review, see Kutas \& Van Petten, 1988). Large N400 amplitudes are elicited by semantically anomalous and unexpected words in both sentential and single-word contexts (see, e.g., Bentin, McCarthy, \& Wood, 1985; Holcomb \& Neville, 1990; Kutas \& Hillyard, 1980, 1984). Since the component was found to be exclusively sensitive to semantic aspects that become part of episodic memory traces, it has been argued that it reflects (post)lexical integration processes, rather than automatic lexical priming (Brown \& Hagoort; 1993; Chwilla, Brown, \& Hagoort, 1995; Halgren \& Smith, 1987; Rugg, 1990; Van Petten \& Kutas, 1990). Thus, the $\mathrm{N} 400$ amplitude appears to be a valid marker for semantic integration processes. ${ }^{2}$

Syntactic integration is correlated with two ERP components differing from N400 in latency, topography, and polarity. The most prominent component elicited by syntactic anomalies is a positive-going waveform with a centro-parietal maximum around $600 \mathrm{msec}$, the so-called P600. This component was found to covary with syntactic anomalies such as garden-path sentences and other syntactically nonpreferred structures (Friederici, Hahne, \& Mecklinger, 1996; Hagoort, Brown, \& Groothusen, 1993; Mecklinger, Schriefers, Steinhauer, \& Friederici, 1995; Osterhout \& Holcomb, 1992; Osterhout, Holcomb, \& Swinney, 1994), as well as with a variety of syntactic violations (Coulson, King, \& Kutas, 1998; Friederici et al., 1996; Friederici, Pfeifer, \& Hahne, 1993; Gunter et al., 1997; Hagoort et al., 1993; McKinnon \& Osterhout, 1996; Neville, Nicol, Barss, Forster, \& Garrett, 1991; Osterhout \& Mobley, 1995). In the case of outright violations, the $P 600$ was often preceded by an additional early left anterior negativity (Coulson et al., 1998; Friederici et al., 1996; Friederici et al., 1993; Gunter et al., 1997; Münte, Heinze, \& Mangun, 1993; Münte, Matzke, \& Johannes, 1997; Neville et al., 1991; Osterhout \& Mobley, 1995; Rösler, Friederici, Pütz, \& Hahne, 1993). These left anterior negativities, however, were observed at different latencies (i.e., at $100-200 \mathrm{msec}$ and at $300-500 \mathrm{msec}$, respectively). The early left anterior negativity between 100 and $200 \mathrm{msec}$ thus far has been observed for the processing of phrase structure violations only. This might suggest that word category information is processed particularly early relative to, for example, agreement and subcategorization information.

In the present experiment, the different properties of the respective ERP components associated with semantic and syntactic processing were employed to investigate whether and how syntax and semantics interact during lexical integration. Sentences were constructed that allowed the introduction of both a semantic and a syntactic violation on the same word. A phrase structure violation was chosen as the syntactic violation because, according to se- 
Table 1

Examples of Stimulus Sentences of the Four Experimental Conditions (1-4) and the Four Filler Conditions (5-8) With Literal Translations

\begin{tabular}{|c|c|c|c|c|c|c|c|}
\hline \multirow{2}{*}{ Condition } & & \multicolumn{5}{|c|}{ Context } & \multirow{2}{*}{$\begin{array}{c}\text { Critical Past } \\
\text { Participle }\end{array}$} \\
\hline & & Determiner & Noun & Auxiliary & Adv/Prep & Noun & \\
\hline \multicolumn{8}{|l|}{ Experimental } \\
\hline Correct & (1) & Das & Haus & wurde & bald & & gebaut. \\
\hline SemMM & (2) & $\begin{array}{l}\text { The } \\
\text { Der } \\
\text { The }\end{array}$ & $\begin{array}{l}\text { house } \\
\text { Priester } \\
\text { priest }\end{array}$ & $\begin{array}{l}\text { was } \\
\text { wurde } \\
\text { was }\end{array}$ & $\begin{array}{l}\text { soon } \\
\text { bald } \\
\text { soon }\end{array}$ & & $\begin{array}{l}\text { built. } \\
\text { gebaut. } \\
\text { built. }\end{array}$ \\
\hline SynMM & (3) & $\begin{array}{l}\text { Das } \\
\text { The }\end{array}$ & $\begin{array}{l}\text { Hausz } \\
\text { house }\end{array}$ & $\begin{array}{l}\text { wurde } \\
\text { was }\end{array}$ & $\begin{array}{l}\text { vom } \\
\text { by the }\end{array}$ & & $\begin{array}{l}\text { gebaut. } \\
\text { built. }\end{array}$ \\
\hline Sem_SynMM & (4) & $\begin{array}{l}\text { Der } \\
\text { The }\end{array}$ & $\begin{array}{l}\text { Priester } \\
\text { priest }\end{array}$ & $\begin{array}{l}\text { wurde } \\
\text { was }\end{array}$ & $\begin{array}{l}\text { vom } \\
\text { by the }\end{array}$ & & $\frac{\text { gebaut. }}{\text { built. }}$ \\
\hline \multicolumn{8}{|l|}{ Filler } \\
\hline Sem_SynMM & (5) & $\begin{array}{l}\text { Das } \\
\text { The }\end{array}$ & $\begin{array}{l}\text { Haus } \\
\text { house }\end{array}$ & $\begin{array}{l}\text { wurde } \\
\text { was }\end{array}$ & $\begin{array}{l}\text { zur } \\
\text { to the }\end{array}$ & & $\begin{array}{l}\text { geholt. } \\
\text { ordered to come. }\end{array}$ \\
\hline PrepCorrect & (6) & $\begin{array}{l}\text { Die } \\
\text { The }\end{array}$ & $\begin{array}{l}\text { Strasse } \\
\text { road }\end{array}$ & $\begin{array}{l}\text { wurde } \\
\text { was }\end{array}$ & $\begin{array}{l}\text { vom } \\
\text { by the }\end{array}$ & $\begin{array}{l}\text { Arbeiter } \\
\text { worker }\end{array}$ & $\frac{\text { gebaut. }}{\text { built. }}$ \\
\hline Correct & (7) & $\begin{array}{l}\text { Der } \\
\text { The }\end{array}$ & $\begin{array}{l}\text { Priester } \\
\text { priest }\end{array}$ & $\begin{array}{l}\text { wurde } \\
\text { was }\end{array}$ & $\begin{array}{l}\text { oft } \\
\text { often }\end{array}$ & & $\begin{array}{l}\text { geholt. } \\
\text { ordered to come. }\end{array}$ \\
\hline PrepCorrect & $(8)$ & $\begin{array}{l}\text { Das } \\
\text { The }\end{array}$ & $\begin{array}{l}\text { Hotel } \\
\text { hotel }\end{array}$ & $\begin{array}{l}\text { wurde } \\
\text { was }\end{array}$ & $\begin{array}{l}\text { am } \\
\text { at the }\end{array}$ & $\begin{array}{l}\text { Strand } \\
\text { beach }\end{array}$ & $\begin{array}{l}\text { gebaut. } \\
\text { built. }\end{array}$ \\
\hline
\end{tabular}

Note-SemMM, semantic mismatch condition; SynMM, syntactic mismatch condition; Sem_SynMM, combined semantic and syntactic mismatch condition; PrepCorrect, correct filler condition containing a prepositional phrase. The critical word is underlined.

rial parsing models, phrase structure assignment should be the most likely candidate to influence further processing without being influenced itself. Four sentence conditions were constructed: (1) correct sentences, (2) sentences with a semantic violation only, (3) sentences with a syntactic violation only (i.e., a word category error), and (4) sentences in which the critical word was both semantically and syntactically incorrect (Table 1).

The hypotheses with respect to the ERP patterns were as follows. For Sentence Type 2, we predicted an N400 component usually observed in correlation with the processing of semantic violations. For Sentence Type 3, we expected components usually seen in correlation with phrase structure errors, namely an early anterior negativity and a P600. The prediction for the ERP pattern of the critical Sentence Type 4, however, was dependent on the particular model under consideration. If one assumes that the amplitude of the N400 marks the ease of integration due to both prior semantic and syntactic context, then one would expect the amplitude of the N400 to be largest for Sentence Type 4. This, however, is not very likely since prior experiments have shown that a word category violation alone does not elicit an $\mathrm{N} 400$, but rather an early left anterior negativity and a P600 (Friederici et al., 1993; Neville et al., 1991). Thus, if phrase structure assignment and semantic integration are processed independently, possible additive effects would result in a combined ERP pattern of Conditions 2 and 3, namely an early left anterior negativity, an N400, and finally a P600. Serial models holding that syntactic congruency between the prior phrase structure and the target word is a precondition for lexical integration to take place, however, would predict that the early negativity, but no typi- cal N400, should be observed in Sentence Type 4. That is, the word category violation would suppress (or at least delay) semantic integration.

\section{METHOD}

\section{Participants}

Sixteen students ( 8 female) of the Free University of Berlin participated as paid volunteers. Their mean age was 26.9 years (range $=21-33$ years). They were German native speakers with normal or corrected-to-normal vision. All participants were righthanded according to the Edinburgh Handedness Inventory (Oldfield, 1971).

\section{Materials}

Stimulus materials consisted of 320 experimental sentences and 320 filler sentences in German. The 320 experimental sentences were used in the four different conditions (see Table 1 and the Appendix for further examples), crossing semantic correctness with syntactic correctness. The resulting conditions were as follows: (1) a completely correct condition (correct), (2) a semantic mismatch condition (SemMM), (3) a syntactic mismatch condition (SynMM), and (4) a combined semantic and syntactic mismatch condition (Sem_SynMM). All experimental sentences were in the passive voice and consisted of five words. The sentence final past participle generally served as the critical element. In the SemMM condition, it mismatched with respect to selectional restriction constraints (e.g., animacy), given the preceding noun phrase. In the SynMM condition, the participle and the preceding context mismatched with respect to phrase structure constraints. In this condition, the preposition von (by), in its case marked form vom (by the [dative] $)$, obligatorily required a noun phrase to follow; that is, the actually presented verb violated the required word category. The combined Sem_SynMM condition contained sentences in which the sentence final past participle and the preceding context mismatched with respect to both semantic restrictions, as in Condition 2, and syntactic constraints, as in Condition $3 .{ }^{3}$ 
In order to adjust the number of words across experimental conditions, adverbs were introduced prior to the sentence final main verb in Conditions 1 and 2 . The occurrence of each noun phrase and of each critical past participle was completely counterbalanced and did not differ across experimental conditions. Four additional filler conditions (Conditions 5-8 in Table 1) with 80 sentences each were constructed mainly for two reasons. First, they counterbalanced the number of correct and incorrect sentences in the design. Second, filler Conditions 6 and 8 introduced sentences that, in contrast to Experimental Conditions 3 and 4, contained correct completions of the prepositional phrases. Thus, reading a preposition did not provide any clue concerning the presence of a subsequent violation in the current sentence.

The experiment used a probe verification paradigm (Van Petten \& Kutas, 1991); that is, each sentence was followed by a probe word, and the participants had to judge whether it had previously occurred in the sentence ("old probe") or not ("new probe"). Except for the completely predictable auxiliary wurde (was), words of all categories served equally often as probes. Morphological variants or semantic relatives of these words were used as new probes. Both old and new probe words of all categories were evenly distributed across conditions. The probe verification task combines different properties that are advantageous in ERP studies like the present one: (1) It requires continuous attentive reading, (2) it does not impose major additional demands, (3) it is compatible with any type of violation under investigation, and (4) it delays overt responses until probe word presentation and thereby helps to avoid undesired response-related ERPs (Van Petten, 1993).

\section{Procedure}

The 640 stimulus sentences were evenly distributed among four blocks of 160 and pseudorandomly intermixed within each block Four different versions with respect to block sequence were used in order to counterbalance sequential effects. Participants were seated in a comfortable chair in a dimly lit room. The sentences were presented visually one word at the time in the center of a 17 -in. computer screen. The words were presented in black letters against a light-gray background for a duration of $300 \mathrm{msec}$ followed by a subsequent interword interval of $200 \mathrm{msec}$. Proportional fonts with a relatively small letter size $(0.4 \mathrm{~cm}$ in height $)$ were used in order to minimize saccadic eye movements during EEG recording. The use of lowercase and capital letters conformed to the rules of German orthography. Participants sat at a distance of $80 \mathrm{~cm}$ from the screen, which yielded an average visual angle of $3.0^{\circ}$ horizontally and $0.3^{\circ}$ vertically per word. Probe words were presented visually $1,100 \mathrm{msec}$ after the offset of the last word of the sentence. Participants were instructed to read the sentences carefully and to give their responses as fast and as accurately as possible. After a pause of $1,000 \mathrm{msec}$, the next trial began. Each experimental session started with a practice block of 16 trials and lasted about $2.5 \mathrm{~h}$ including pauses, electrode application, and removal.

\section{EEG Recording}

The EEG activity was recorded by means of tin electrodes mounted in an elastic cap (Electro-Cap International) from 15 electrode sites, based on the International 10-20 System (Fz, Cz, Pz, Fp1, Fp2, F3, F4, F7, F8, P3, P4, T5, T6, O1, O2). All electrodes were referenced to linked mastoids. The ground electrode was positioned $10 \%$ of the nasion-inion distance anterior to Fz. Eye movements were monitored by the vertical and the horizontal EOG separately. Electrode impedances were kept below $5 \mathrm{k} \Omega$. The EEG and EOG channels were amplified by Neuroscan amplifiers (dc to $30 \mathrm{~Hz}$ ). EEG and EOG were recorded continuously for each block of trials and were $A / D$ converted with 12-bit resolution at a rate of $250 \mathrm{~Hz}$. Data collection was controlled by an IBM-compatible 486 computer.

\section{Data Analysis}

Behavioral data. RT was defined as the interval between the onset of the probe word and the participants' keypress. All of the RT averages were composed of correct responses. Performance data were quantified separately with respect to RT and accuracy.

ERP data. Off-line separated ERPs were averaged for each participant at each electrode site from trials free of EOG artifacts in each condition. The rejected trials due to artifacts were equally distributed over the different conditions with a mean of $32.27 \%(S D=$ $15.78)$ for the correct sentences, a mean of $23.98 \%(S D=10.44)$ for the incorrect sentences of the syntactic-mismatch condition, a mean of $26.56 \%(S D=10.73)$ for the sentences of the semantic-mismatch condition, and a mean of $28.91 \%(S D=11.87)$ for the sentences containing the double mismatch. ${ }^{4}$ ERPs were time-locked to the onset of the last three words in each sentence. A time window of $500 \mathrm{msec}$, including the presentation of the auxiliary wurde (was) (of $300 \mathrm{msec}$ ) plus the following interword interval of $200 \mathrm{msec}$ was generally used to compute the baseline. ERPs time-locked to the onset of the sentence final past participle were quantified in three different time windows, (1) between 100 and $150 \mathrm{msec}$ (ELAN), (2) between 300 and $500 \mathrm{msec}(\mathrm{N} 400)$, and (3) between 500 and $800 \mathrm{msec}(\mathrm{P} 600)$ on the basis of a visual inspection of the grand averages. In order to yield a more fine-grained resolution of the time course of the effects, we also computed analyses of 10 subsequent 50 -msec time windows between 300 and $800 \mathrm{msec}$ after onset of the past participle. In addition, ERPs time-locked to the word preceding the critical word were analyzed for a possible word class effect (adverb vs. preposition) in the time window $300-500 \mathrm{msec}$ after onset of the penultimate word. Since this word class effect spilled over into the time domain of the critical past participle, additional analyses were conducted using a very local baseline interval (see below). The ERP data were analyzed separately for midline and lateral electrode sites. The global analysis of variance (ANOVA) for the midline electrodes included the factors semantics (correct vs. mismatch), syntax (correct vs. mismatch), and electrode ( $\mathrm{Fz}, \mathrm{Cz}, \mathrm{Pz}$ ). To examine the topographic distribution of the different ERP measures, four quadrants, each comprising three lateral electrodes, were defined, namely the left anterior (Fpl, F3, F7), the right anterior (Fp2, F4, F8), the left posterior ( $\mathrm{P} 3, \mathrm{~T} 5, \mathrm{O} 1$ ), and the right posterior quadrant $(\mathrm{P} 4, \mathrm{~T} 6, \mathrm{O} 2)$. Thus, the global ANOVA for the lateral electrodes included the factors semantics (2), syntax (2), hemisphere (left vs. right), and region (anterior vs. posterior). Where interactions with topographic variables are reported, ANOVAs were also performed for $Z$-score-normalized data. This normalization procedure equalizes the mean amplitudes across conditions and is similar to the procedure proposed by McCarthy and Wood (1985). To protect against excessive Type 1 errors resulting from violations of sphericity, the Huynh and Feldt (1970) correction was applied when effects with more than $1 d f$ in the numerator were evaluated. In these cases, we report the original degrees of freedom and the corrected probability level.

\section{RESULTS}

\section{Behavioral Data}

Table 2 presents mean RTs and performance accuracy for each of the experimental conditions. As is apparent from the table, there was a tendency for sentences including a syntactic mismatch (SynMM and Sem_SynMM) to induce longer probe verification times. Interestingly, a semantic mismatch alone did not lead to an increase in the probe identification time relative to that for correct sentences. Performance accuracy was particularly affected by the double mismatch (Sem_SynMM). 


\begin{tabular}{lcrcc} 
Table 2 & Mean Probe Identification Times \\
& $\begin{array}{c}\text { Men } \\
\text { (Reaction Times, in Milliseconds), Percent Correct, } \\
\text { and Standard Deviation as a Function of Condition }\end{array}$ \\
\hline Condition & $M$ & $S D$ & \% Correct & $S D$ \\
\hline Correct & 693 & 110 & 96.3 & 3.4 \\
SemMM & 694 & 98 & 95.4 & 4.7 \\
SynMM & 715 & 110 & 95.5 & 3.8 \\
Sem_SynMM & 706 & 107 & 94.0 & 5.4 \\
\hline
\end{tabular}

Note-SemMM, semantic mismatch condition; SynMM, syntactic mismatch condition; Sem_SynMM, combined semantic and syntactic mismatch condition.

These observations were confirmed statistically. An ANOVA with the factors semantics $\times$ syntax for the probe RTs revealed a main effect of syntax $[F(1,15)=11.7, p<$ $.005]$. Both conditions including a syntactic mismatch differed significantly from the correct condition [SynMM vs. correct, $F(1,15)=12.03, p<.005 ;$ Sem_SynMM vs. correct, $F(1,15)=10.9, p<.005]$. The difference between SemMM and Sem_SynMM was marginally significant $[F(1,15)=4.29, p<.06]$. The ANOVA for the accuracy data with the same factors revealed a marginally significant main effect of semantics $[F(1,15)=3.49, p<.08]$ that was mainly due to a significant difference between the Sem_SynMM condition and the correct condition $[F(1,15)=6.8, p<.05]$. No other comparison reached significance.

\section{Event-Related Potentials}

Figure 1 shows the grand averages of the ERPs in a 2,000-msec time interval beginning with the onset of the auxiliary wurde (was) (as indicated at $-1,000 \mathrm{msec}$ ) up to $1,000 \mathrm{msec}$ postonset of the sentence final past participle. The interval thus included the presentation of the last three words. Note that the onset of the critical past participle (at $0 \mathrm{msec}$ ) is generally used as a reference for the time scales. As a consequence, the onset of the auxiliary in Figure 1 was at $-1,000 \mathrm{msec}$ and that of the penultimate word (adverb or preposition) at $-500 \mathrm{msec}$. In this plot, ERPs of all four conditions are superimposed. The time window between onset of the auxiliary (AUX) and onset of the penultimate word (i.e., the interval between $-1,000$ and $-500 \mathrm{msec}$ ) was used to compute the respective baselines. Negative amplitudes are always plotted upward.

The penultimate word. Recall that the penultimate word was an adverb (Adv) in the correct and the SemMM conditions, and a preposition (Prep) in the SynMM and in the Sem_SynMM conditions (Table 1). During the first $300 \mathrm{msec}$ after stimulus onset (i.e., between -500 and $-200 \mathrm{msec}$ in Figure 1), the waveforms of the four conditions were very similar: A frontal negative N100 component peaking at about $-400 \mathrm{msec}$ was followed by a positive $\mathrm{P} 200$ component peaking at around $-300 \mathrm{msec}$. Subsequently, between 300 and $500 \mathrm{msec}$ after the onset of the penultimate word (i.e., between -200 and $0 \mathrm{msec}$ in Figure 1), a pronounced negative component (N400) was visible with larger amplitudes for the two conditions containing an adverb (i.e., correct and SemMM) relative to the two conditions containing a preposition (i.e., SynMM and Sem_SynMM). Statistical analyses of this word class difference in N400 amplitudes were calculated separately for the midline electrodes and the four lateral quadrants. The ANOVA for the midline electrodes with the factors semantics $\times$ syntax $\times$ electrode revealed a significant main effect of syntax $[F(1,15)=7.03, p<.05]$ and a semantics $\times$ electrode interaction $[F(2,30)=4.4, p<$ $.05]$. The ANOVA for the lateral electrodes with the factors semantics $\times$ syntax $\times$ hemisphere $\times$ region revealed a main effect of syntax $[F(1,15)=5.25, p<.05]$ and a significant syntax $\times$ hemisphere interaction $[F(1,15)=$ $5.44 p<.05]$. This interaction was due to the $\mathrm{N} 400$ effect's being larger over the right hemisphere $[F(1,15)=7.28$, $p<.02]$ than over the left $[F(1,15)=2.99, p=.10]$. Note that at posterior electrode sites (e.g., $\mathrm{O} 1$ and $\mathrm{O} 2$ ), the word category effect was still present during the first $250 \mathrm{msec}$ after onset of the past participle (spillover effect).

The finding of a main effect of word category (adverb vs. preposition) of the actual size was not expected. Although it is known that content words evoke significantly larger N400 amplitudes than do function words (Neville, Mills, \& Lawson, 1992; Nobre \& McCarthy, 1994; Van Petten \& Kutas, 1991), it is not clear from these publications what the expected ERP patterns for adverbs and prepositions are. ${ }^{5}$ Both word categories may be viewed as members of the closed class. However, with respect to prepositions, it was shown that locative prepositions carrying semantic meaning do not cluster behaviorally with other closed class words, whereas prepositions with a purely syntactic status do (Friederici, 1985). Adverbs are not less problematic; there is a debate in linguistics regarding whether they should be classified as members of the open or closed class (e.g., Friederici \& Saddy, 1993; O'Grady, Dobrovolsky, \& Aronoff, 1989). The present finding of a larger $\mathrm{N} 400$ for the adverbs than for the prepositions suggests that adverbs should be viewed as clustering with open class elements since they elicit an ERP pattern similar to that of other members of the open class. But again the similarity to the processing of open class elements may be a function of the amount of semantic information a given adverb carries. ${ }^{6}$

The critical word. Since the word class N400 of the penultimate word might have influenced the computation of a prestimulus baseline for the past participle, we decided to use the previous baseline also for all main analyses concerning ERP effects after the onset of the past participle. The onset of the critical past participle is indicated in Figure 1 by the vertical line at $0 \mathrm{msec}$. Again, the waveforms of all four conditions displayed a uniform N100-P200 pattern and almost matched during the first $300 \mathrm{msec}$. The ERPs, however, varied specifically beyond 


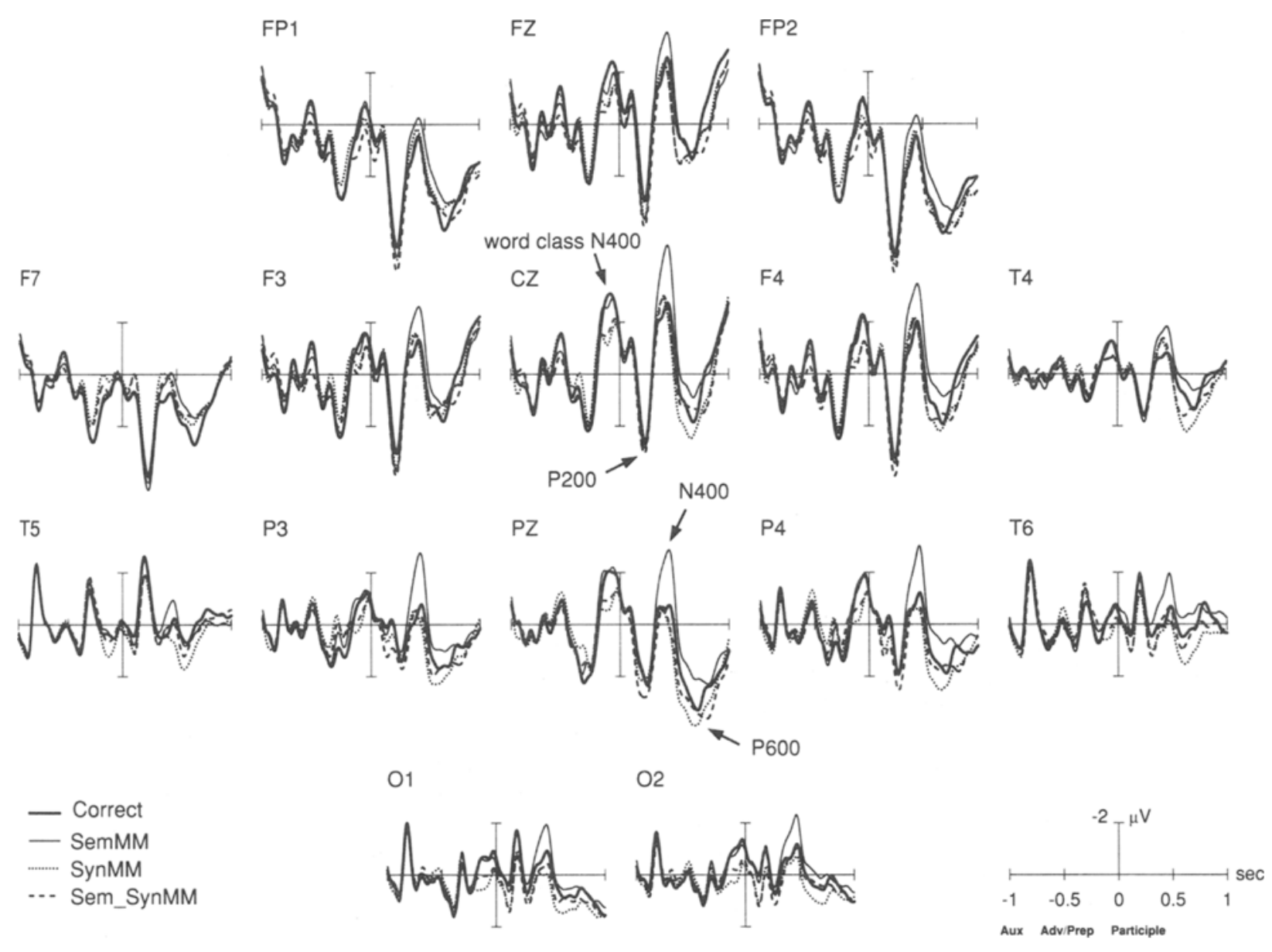

Figure 1. Grand average ERPs at all electrodes in the time interval from the onset of the auxiliary up to 1,000 msec postonset of the past participle (baseline consists of the first 500 msec postonset of the auxiliary). The waveforms are superimposed for the four experimental conditions. The onset of the auxiliary is at $-1 \mathrm{sec}$, that of the adverb/preposition is at $-0.5 \mathrm{sec}$, and the onset of the past participle is at 0 sec, marked by a vertical line. The relevant components are marked by arrows. SemMM, semantic mismatch condition; SynMM, syntactic mismatch condition; Sem_SynMM, combined semantic and syntactic mismatch condition.

$300 \mathrm{msec}$ as a function of the corresponding mismatch conditions. Next we will consider the ERP component indicating semantic lexical integration processes and then components correlated with syntactic processes.

The N400 component. Most prominently, a large N400 component was visible for the SemMM condition between 300 and $500 \mathrm{msec}$. In contrast, the amplitudes of this negative component in both the SynMM condition and the Sem_SynMM condition do not seem to have differed from the correct condition in the N400 time window. This observation was confirmed by statistical analyses. An ANOVA in the time window 300-500 msec for the midline electrodes with the factors semantics $\times$ syntax $\times$ electrode revealed a main effect of semantics $[F(1,15)=$ $5.11, p<.05]$, a main effect of syntax $[F(1,15)=5.63$, $p<.05]$, and a highly significant semantics $\times$ syntax interaction $[F(1,15)=11.72, p<.005]$. This interaction was due to the negativity's being increased exclusively in the SemMM condition. The difference between the correct and the SemMM conditions was significant $[F(1,15)=$
$17.67, p<.001]$, whereas the difference between the SynMM and the Sem_SynMM conditions was not $(F<1)$. The ANOVA for the lateral electrodes with the factors semantics $\times$ syntax $\times$ hemisphere $\times$ region showed a significant main effect of semantics $[F(1,15)=7.55, p<$ $.05]$ and a semantics $\times$ syntax interaction $[F(1,15)=$ $9.55, p<.01]$. Again, this interaction was due to a significant difference between the correct and the SemMM conditions $[F(1,15)=15.25, p<.005]$ and the absence of a significant difference between the SynMM and the Sem_SynMM conditions $(F<1)$. Furthermore, neither the SynMM nor the Sem_SynMM condition differed significantly from the correct condition (midline and lateral: $F$ values $<2 ; p$ values $>.6$ ). As the more fine grained analyses shown in Table 3 reveal, this pattern held for each $50-\mathrm{msec}$ window between 300 and $500 \mathrm{msec}$ at both the midline and the lateral electrode sites.

Visual inspection of Figure 1 may suggest that the early variability across conditions in the P200 window contributed to the N400 null effect in the double violation 
Table 3

Effects ( $p$-values) at Midline and Lateral Electrode Sites in 50-Msec

Time Windows Between 300 and 800 Msec After Onset of the Past Participle

\begin{tabular}{|c|c|c|c|c|c|c|c|c|c|c|c|}
\hline \multirow[b]{2}{*}{ Component } & \multirow[b]{2}{*}{ Source } & \multicolumn{10}{|c|}{ Time Window $(\mathrm{msec})$} \\
\hline & & $300-350$ & $350-400$ & $400-450$ & $450-500$ & $500-550$ & $550-600$ & $600-650$ & $650-700$ & $700-750$ & $750-800$ \\
\hline \multicolumn{12}{|c|}{ Midline } \\
\hline \multirow[t]{2}{*}{ N400 } & Semantics & & .06 & .006 & .01 & .09 & & & & & \\
\hline & Semantics*Syntax & .02 & .005 & .002 & .02 & & & & & & \\
\hline N400/Late negativity & Semantics*Electrode & & & .03 & .06 & & .05 & .06 & & .05 & \\
\hline \multirow{2}{*}{ P600 } & Syntax & & & .003 & .003 & .01 & .04 & .07 & & & \\
\hline & Syntax $*$ Electrode & & & .02 & & & & & .05 & & \\
\hline \multicolumn{12}{|c|}{ Lateral } \\
\hline N400 & Semantics*Syntax & .01 & .002 & .008 & .05 & & & & & & \\
\hline N400/Late negativity & Semantics & & .05 & .003 & .003 & .06 & .04 & .01 & .02 & .08 & \\
\hline \multirow[t]{2}{*}{ Late negativity } & Semantics*Hemisphere & & & & & & & .04 & .02 & .04 & \\
\hline & Syntax & & & & .01 & .04 & .05 & .05 & & & \\
\hline \multirow[t]{2}{*}{ P600 } & Syntax*Hemisphere & & .05 & & & & .01 & .001 & .001 & .01 & .01 \\
\hline & Syntax*Hemisphere*Position & & & & & .007 & .002 & .005 & .006 & & \\
\hline P600 + Late negativity & Semantics*Syntax*Hemisphere*Position & & & & & & .07 & .07 & .07 & & \\
\hline
\end{tabular}

condition, especially at PZ. That is, the N400 might have been masked by an early positive slow wave. In order to rule this possibility out, we computed a peak-to-peak analysis between $\mathrm{P} 200$ and $\mathrm{N} 400$ at the $\mathrm{PZ}$ electrode for each condition. Note that this type of analysis is completely independent of any baseline. The statistical analysis revealed exactly the same pattern as in our previous analyses. Most importantly, a highly significant semantics $\times$ syntax interaction $[F(1,15)=10.31, p<.006]$ was due only to the enhanced $\mathrm{N} 400$ in the semantic violation condition $[F(1,15)=14.37, p<.002]$, whereas no other conditions differed from one another $(F<1)$. Moreover, none of the filler conditions differed from the correct condition (1) $(p>3)$. The same was true for comparisons with the correct filler condition (7). Taken as a whole, there was no indication of a masked N400 effect in either of the two double violation conditions ( 4 and 5, respectively). The results of the peak-to-peak analysis at the PZ electrode site are illustrated in Figure 2.

The $P 600$ reflecting late syntax effects. A late positivity was visible in the time range between 500 and $1,000 \mathrm{msec}$ postonset of the past participle at posterior electrode sites with larger amplitudes in the two syntactically incorrect conditions relative to the syntactically correct conditions (Figure 1). Statistical analyses in the time window between 500 and $800 \mathrm{msec}$ revealed a main effect of syntax $[F(1,15)=4.84, p<.05]$ at the midline electrodes. At lateral electrode sites, we found a marginal syntax main effect $[F(1,15)=4.37, p<.06]$, a syntax $\times$ hemisphere interaction $[F(1,15)=15.87, p<.005$ (normalized, $F(1,15)=$ $17.79, p<.001)]$, and a syntax $\times$ hemisphere $\times$ region interaction $[F(1,15)=10.14, p<.01$ (normalized, $F(1,15)$ $=9.57, p<.01)]$. Separate analyses for each hemisphere and each quadrant revealed a significant syntax effect in the right $[F(1,15)=6.30, p<.05]$ but not in the left $(p>.1)$ hemisphere, which was most reliable at right posterior electrodes $[F(1,15)=6.93, p<.05] .^{7}$ The re- sulting ERP patterns elicited after onset of the critical word (past participle) are further illustrated in Figure 3 as difference curves, which were obtained by substracting the ERP pattern in the control condition (correct) from the ERP pattern in each of the three violation conditions. Note that the onsets of the P600 components were identical in the purely syntactic and the double mismatch condition. That is, we did not find any indication for an earlier onset of the positivity in the Sem_SynMM condition that could have masked a preceding $\mathrm{N} 400$ effect. ${ }^{8}$

The early negativity reflecting initial syntax processing. Possible processes suppressing the N400 should be expected in a time window preceding the $\mathrm{N} 400$ component. One component to be expected in correlation with early syntactic processes is the early left anterior negativity found to be elicited by word category violations in a time range of about 100-200 msec (Friederici et al., 1996; Friederici et al., 1993). In the present study, however, the word class $\mathrm{N} 400$ effect of the penultimate words (i.e., smaller N400 amplitudes for prepositions than for adverbs) spilled over into this very time window. This spillover effect is illustrated in Figure 3 by difference waveforms (i.e., SynMM minus correct and Sem_SynMM minus correct) that display a posterior positivity between 100 and $200 \mathrm{msec}$. It is not unlikely that at more anterior electrodes this spillover effect partly superimposes the expected early negativity usually found in syntactic violation conditions. Thus, an early negativity between 100 and $150 \mathrm{msec}$ for both syntactic mismatch conditions was observed at the left anterior electrode F7 only. Owing to the spillover effect, the waveforms for the same conditions were more positive at posterior electrode sites. Statistical analyses revealed a significant syntax $\times$ region interaction $[F(1,15)=14.72, p<.0016]$. The posterior effect due to word class differences of the penultimate word reached significance $[F(1,15)=6.23, p<.0247]$. No such effect was found at anterior electrode sites $(F<1)$. 
P200-N400 $[\mu \mathrm{V}]$

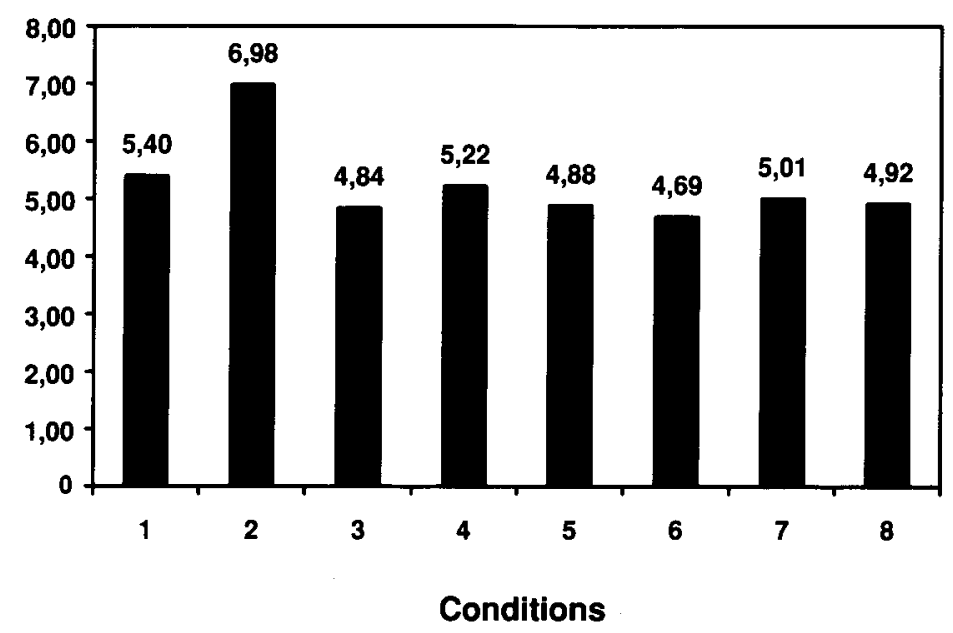

Figure 2. Peak amplitude differences between P200 and N400 for all eight conditions, including filler sentences at the $P Z$ electrode. The peak-to-peak measures are based on the individual data of each participant.

Focusing on the early left anterior negativity, we conducted separate analyses for the left anterior electrodes. At F7 there was a marginally significant main effect of syntax $[F(1,15)=3.64, p<.07]$, with a more negative-going wave for the syntactically incorrect relative to the syntactically correct conditions. These analyses suggest that a possible early negativity elicited by the past participle was partly eliminated at other frontal electrode sites due to the late part of the word class effect of the penultimate word. This argument is supported by additional analyses using a 100 -msec baseline from $50 \mathrm{msec}$ preonset of the past participle until $50 \mathrm{msec}$ thereafter, thus compensating for the N400 word class effect of the penultimate word. The ANOVA investigating the early negativity was calculated for the lateral electrodes with the factors semantics $\times$ syntax $\times$ hemisphere $\times$ region in the time window $100-150$ msec postonset of the past participle. We obtained a significant syntax $\times$ region interaction $[F(1,15)=$ $20.75, p<.001]$, a semantics $\times$ region interaction $[F(1,15)$ $=5.58, p<.05]$, and a semantics $\times$ syntax $\times$ hemisphere $\times$ region interaction $[F(1,15)=6.14 p<.05]$. Separate analyses for both anterior and posterior electrodes revealed a significant early negativity syntax effect in the anterior region $[F(1,15)=4.44, p=.05] .{ }^{9}$

$A$ late negativity. The different mismatch conditions, moreover, showed differential effects in a late time window between 600 and 850 msec (Figure 3). The SemMM condition with its prominent $\mathrm{N} 400$ effect displayed a second negativity peaking around $750 \mathrm{msec}$, larger over the right than over the left hemisphere. This late negativity was also present in the double violation condition (Sem_SynMM) relative to the purely syntactic violation condition (SynMM). Table 3 gives an overview of the time course of the different late effects as revealed by an
ANOVA of consecutive time windows of $50 \mathrm{msec}$ between 300 and $800 \mathrm{msec}$ ( $p$ values).

\section{DISCUSSION}

In this paper, we have investigated the temporal structure of lexical integration with respect to semantic and syntactic aspects using ERPs. Each lexical element to be integrated into the prior sentence context has to meet particular syntactic and semantic constraints. Behaviorally it has been observed that a semantic mismatch between the context and the target word leads to longer RTs in word recognition tasks (Collins \& Loftus, 1975; Meyer \& Schvaneveldt, 1971; Neely, 1991). In syntactic mismatch conditions, target integration into the context is also delayed (Friederici \& Kilborn, 1989; West \& Stanovich, 1986; Wright \& Garrett, 1984). Thus, these studies suggest that both aspects play a role during lexical integration. Whether and how these aspects interact was investigated in the present ERP study. The sentence material consisted of sentences whose final word was either congruent with the preceding context or incongruent because of a phrase structure violation, a semantic violation, or both. The main results correlated with the different types of violations can be summarized as follows. First, for the purely semantic violation condition, we observed a clear N400 effect. Second, no N400 effect was found for the semantically and syntactically incorrect target. Third, both sentence types carrying a semantic error elicited a late centro-parietal negativity around $700 \mathrm{msec}$. Fourth, both sentence types including a syntactic error evoked a marginally significant early negativity and a late positivity (i.e., a P600). In the following discussion, we will take up each of these effects in turn. 

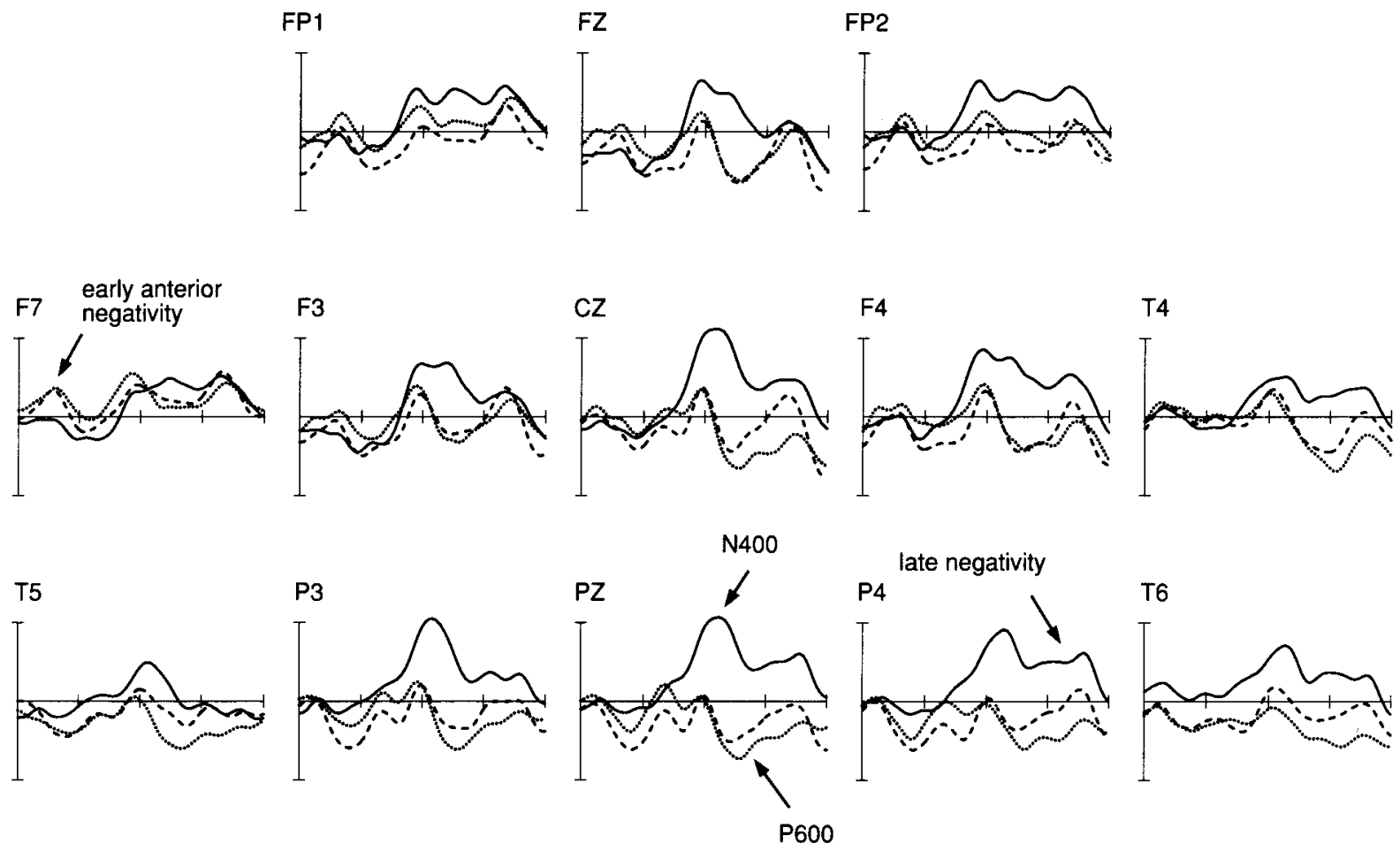

Difference waves:

01

- SemMM Corr

........ SynMM Corr

-.-Sem_Syn Corr
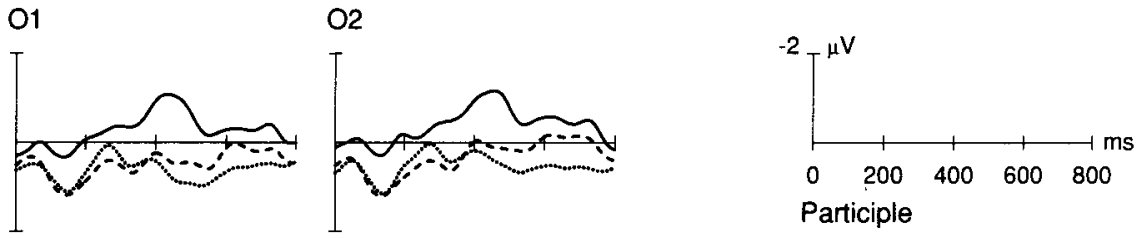

Figure 3. Difference curves of the grand average ERPs at all electrodes between the control condition (correct) and each of the three violation conditions. (As in Figure 1, the baseline consists of the first $500 \mathrm{msec}$ postonset of the auxiliary and is not plotted.) Zero msec marks the onset of the critical word (past participle). Amplitude differences referred to in the text are marked by arrows.

\section{The N400 Effects}

For the purely semantic violation condition, we observed the expected $\mathrm{N} 400$ effect, similar to those repeatedly found in correlation with lexical-semantic processes (Kutas \& Van Petten, 1988). A number of studies suggest that the $\mathrm{N} 400$ can be taken as a marker of lexicalsemantic integration processes (e.g., Chwilla et al., 1995; Halgren \& Smith, 1987; Rugg, 1990). The large N400 amplitude in the SemMM condition seems to reflect the semantic incongruency and low cloze probability of the target word (Kutas, Lindamood, \& Hillyard, 1984). Most importantly, no such N400 effect was found for sentences whose past participle created a syntactic in addition to a semantic mismatch. This (baseline-independent) pattern could not be attributed to a component overlap and was replicated in the filler condition (5), which carried the same type of double violation. The reduction or even absence of an $\mathrm{N} 400$ effect in this condition was predicted by serial models assuming that a correct phrase structure is a precondition for lexical-semantic integration processes to take place. The present findings suggest that a phrase structure violation can block subsequent lexical integration. With respect to the underlying mechanism, two alternatives can be conceived. It may be that the word category information on which phrase structure assignment operates is accessed earlier than other lexical aspects and, therefore, affects further lexical integration processes online. Or, the observed effect may be due to postlexical checking mechanisms. ${ }^{10}$ The general interpretation suggesting an interruption of semantic processing due to phrase structural violations is in agreement with a recent series of behavioral experiments carried out by O'Seaghdha (1997). Crossing local phrase structure violations with semantic violations in both lexical decision and naming tasks, he found semantic relatedness effects to be considerably smaller (or even absent) if the target word violated the required word category. The inhibitory effect of a word category violation, however, was robust across all conditions and experiments.

The present ERP findings are in apparent contrast to results reported by Van Petten and Kutas (1991), who investigated the $\mathrm{N} 400$ component in different syntactic 
contexts (i.e., congruent context, syntactically correctsemantically anomalous context, and random word order context) and at various word positions in the sentence. The authors noted that they found "no evidence that the constraints available in syntactic sentences were capable of reducing N400 amplitude for open-class words, whereas semantic context produced a linear decrement in amplitude across the course of a sentence" (p. 102). Their data seem to suggest that content words have a priori large N400 amplitudes that can successively be attenuated by a cumulative semantically congruent context only. No such attenuation was found for the two anomalous conditions. For the scrambled sentences, however, a positive slow wave was observed. Originally it was interpreted to reflect decreasing arousal (Van Petten \& Kutas, 1991), and later it was reinterpreted in favor of a series of subsequent P600 components (Van Petten, 1993).

The contrast between their N400 findings and our result of a very small $\mathrm{N} 400$ in the double violation conditions can be explained by the different types of syntactic contexts used in the Van Petten and Kutas (1991) study and in the present study, respectively. The main difference between the two studies is that the syntactically incorrect context used by Van Petten and Kutas (1991) contained no syntactic structure at all--that is, all words were scrambled - whereas the one used in the present study contained only a local syntactic violation on the critical word. Thus the former context type, in contrast to the latter, did not allow the building of a phrase structure, the constraints of which could subsequently be violated, let alone reanalyzed. That is, if confronted with scrambled word strings, the parser could be assumed to be "switched off," no longer guiding lexical integration. In contrast, at local syntactic violations within a previously congruent phrase structure, as used in the present study, the parser may react in its usual mode: The violation must be reanalyzed or repaired in order to achieve licensed argument relations that determine the specific selectional restrictions necessary for a comprehensive interpretation. ${ }^{11}$ The different findings in the two studies strongly suggest that the mode of semantic integration in word lists or scrambled word sequences differs considerably from that in normal grammatical sentences. It is in the latter case that specific semantic relations which are completely dependent on the structural analysis (i.e., thematic roles and associated selectional restrictions) can override more general types of semantic relatedness. Thus, local discrepancies of the underlying phrase structure appear to be similarly effective in blocking semantic integration, as instructions of shallow physical processing in the Chwilla et al. (1995) study. This study is of major concern because it demonstrated that a letter case discrimination task that did not require semantic processing did not elicit $\mathrm{N} 400$ components, either. Thus, small N400 amplitudes turned out to be due either to smooth semantic integration (i.e., priming) or to the absence of semantic integration. In the present study, the priority of recovering from local phrase structure violations obviously interrupted further (semantic) integration processes in a similar way.

\section{The Late Negativity}

In addition to the $\mathrm{N} 400$ component, both semantic violation conditions displayed a late negativity around $700 \mathrm{msec}$ that was widely distributed over the right hemisphere. The finding that this negativity, in contrast to the $\mathrm{N} 400$, was present in both semantically incongruent conditions (SemMM and Sem_SynMM) suggests that this component may be taken to reflect secondary semantic processes. At first glance, this interpretation seems to contradict our previous assumption that semantic integration was blocked in the double violation condition. However, the late negativity was elicited only after the onset of the P600. If - as we assume-the P600 does reflect processes of structural reanalysis and repair, then semantic interpretation of an already repaired structure may indeed take place. ${ }^{12}$ Negativities in this late time window have been observed in previous ERP studies on sentence processing, although with a different topography: A sustained frontal negativity was found to be present at the phrase boundary (Friederici et al., 1996), and slow potentials called "clause ending negativities" were observed at the end of clauses (Kutas, 1997). The latter negativity was attributed to working memory load due to integration processes. Mecklinger et al. (1995) also assumed a late negativity with a left hemispheric maximum to be correlated with memory load. The present late negativity, however, has its maximum over the right hemisphere, including frontal, central, and parietal sites. Moreover, the negativity reported here occurred only in semantic violation conditions. Future research will have to specify the functional relevance of this component. One tentative interpretation is that rehearsal processes due to the employed probe verification task might have led to secondary semantic integration processes.

\section{The Early Negativity}

Previous studies using the same kind of phrase structure violations but in connected speech showed an early left anterior negativity mostly followed by a late positivity (Friederici et al., 1996; Friederici et al., 1993; Hahne \& Friederici, 1999). In the present study, the early negativity of the critical past participle was only marginally significant. Additional analyses, however, showed that a temporal spillover of the preceding word class effect may have led to a reduction of the early anterior negativity. The combined data suggest that this component reflects firstpass parsing processes and, more specifically, the inability to assign the incoming word to the current phrase structure (Friederici, 1995). Moreover, the presence of the early negativity in the absence of an N400 effect in the double violation conditions strongly points to a primacy of firstpass parsing processes over semantic integration.

\section{The P600}

A P600 effect was present in both syntactic violation conditions and was also observed in the double violation filler condition (5). It has been argued that this component may reflect the costs of reprocessing (Osterhout \& Holcomb, 1992) or, more specifically, processes of syn- 
tactic reanalysis and repair (Friederici et al., 1996; Friederici \& Mecklinger, 1996). The fact, however, that the P600 difference in our study was relatively small (in particular, in the double violation condition) relative to effects reported in previous studies needs some explanation. At least three different aspects may be considered: First, the relatively high percentage of syntactic violations may have reduced the P600 effect (see Hahne \& Friederici, 1999). Second, final words in sentences containing syntactic violations may occasionally induce a relative negative shift in sentence final positions (see, e.g., McKinnon \& Osterhout, 1996). Third, the late part of the P600 in the double violation condition was partly superimposed by the late negativity peaking around $700 \mathrm{msec}$.

\section{Crossing Syntax and Semantics}

With respect to the issue of syntactic context effects and lexical-semantic context effects on word processing, the present data suggest that both information types affect lexical integration processes. The presence of the $\mathrm{N} 400 \mathrm{effect}$ in the semantically incongruent condition indicates the influence of prior semantic information on word processing. This supports a well-established view in the behavioral (e.g., Neely, 1991) and the ERP (e.g., Van Petten, 1993) literatures. The absence of the N400 effect in the syntactically and semantically incongruent condition, and its presence in the purely semantic violation condition, confirm that at least certain syntactic aspects (i.e., word category information) can influence processes of semantic lexical integration. This view is in general agreement with results from RT studies showing that a semantic priming effect can be influenced by syntactic aspects of the prior context (O'Seaghdha, 1989, 1997; Schriefers et al., 1998). The present data, however, provide more specific information about the temporal course of this influence because they show that the N400 effect is dependent on the syntactic correctness of the local context. This finding suggests that attempts to integrate a lexical element into prior sentential context are initiated only once certain syntactic requirements, such as a legitimate word category, are fulfilled. The observed blocking of lexical-semantic integration seems possible only under the precondition that initial processes of phrase structure assignment precede semantic processes. It remains open whether the observed sequential effects of syntactic word category information and semantic information are due to their serial availability during lexical access or to a primacy of word category information during postlexical checking processes.

The present study seems to be only in partial agreement with a recent investigation in Dutch (Gunter et al., 1997) that also crossed the factors of syntactic correctness and semantic congruency. As in the present study, they found a P600 for the syntactic violation and an N400 for the semantic violation. However, their the double violation condition elicited a biphasic pattern-that is, an N400 followed by a P600. ${ }^{13}$ This difference from the present study can be explained if one considers the type of syntactic violation in the Gunter et al. study, which was realized as an inflectional error (i.e., the past participle was replaced by the infinitive verb form), whereas in the present study it was realized as a word category error (verb instead of noun). According to our model (Friederici, 1995), information about a word's syntactic category may well be available prior to information about the particular morphology of a verb, since the former but not the latter is necessary for local phrase structure building. The different findings of the two studies can in fact be explained by a privileged status of word category information in parsing processes.

\section{Conclusion}

The major contribution of the present study is to outline a data-based conception of lexical integration that can account for the seemingly contradictory findings of several extant behavioral and ERP studies. The proposal specifies the basic underlying processes, their time course, and their interactions. By contrasting the mode of integration in sentences with that of word lists and random word sequences, crucial differences become obvious. Only in well-formed phrases and sentences does phrase structure assignment seem to be the initial and autonomous process that guides further specific integration processes which crucially depend on phrase structural relations, such as syntactic checks of feature agreement or semantic operations (e.g., role assignment). In random word sequences, however, phrase structure assignment cannot take place and semantic integration may rely on more general types of semantic relations (e.g., associations) instead. Only in a well-formed structure, therefore, may a word category mismatch be sufficient to initially interrupt any further integration processes. Since word category information is essential for phrase structure building, it needs to be distinguished from both semantic information and other syntactic information (e.g., syntactic gender), which are assumed to be processed later during lexical integration.

\section{REFERENCES}

Ainsworth-Darnell, K., Shulman, H. G., \& Boland, J. E. (1998). Dissociating brain responses to syntactic and semantic anomalies: Evidence from event-related potentials. Journal of Memory \& Language, 38, 112-130.

ANDERSON, J. R. (1983). The architecture of cognition. Cambridge, MA: Harvard University Press.

BECKER, C. A. (1980). Semantic context effects in visual word recognition: An analysis of semantic strategies. Memory $\&$ Cognition, 8 , 493-512.

BECKER, C. A. (1985). What do we really know about semantic context effects during reading? In D. Besner, T. G. Waller, \& E. M. McKinnon (Eds.), Reading research: Advances in theory and practice (Vol. 5, pp. 125-169). Toronto: Academic Press.

Bentin, S., McCarthy, G., \& Wood, C. C. (1985). Event-related potentials associated with semantic priming. Electroencephalography \& Clinical Neurophysiology, 60, 343-355.

Boland, J. E., Tanenhaus, M. K., Garnsey, S. M., \& Carlson, G. N. 
(1995). Verb argument structure in parsing and interpretation: Evidence from wh-questions. Journal of Memory \& Language, 34, 774 806.

Brown, C. M., \& HAGoorT, P. (1993). The processing nature of the $\mathrm{N} 400$ : Evidence from masked priming. Journal of Cognitive Neuroscience, 5, 34-44.

BURNAGE, G. (1990). CELEX: A guide for users. Nijmegen: SSN.

Chwilla, D. J., Brown, C. M., \& HAGOORT, P. (1995). The N400 as a function of the level of processing. Psychophysiology, 32, 274-285.

Collins, A. M., \& Lofrus, E. F. (1975). A spreading-activation theory of semantic processing. Psychological Review, 82, 407-428.

Coulson, S., KInG, J., \& KuTAS, M. (1998). Expect the unexpected: Event-related brain response to morphosyntactic violations. Language \& Cognitive Processes, 13, 21-58.

COWART, W. (1982). Autonomy and interaction in the language processing system: A reply to Marslen-Wilson and Tyler. Cognition, 12, 109-117.

Deutsch, A., \& Bentin, S. (1994). Attention mechanisms mediate the syntactic priming effect in auditory word identification. Journal of Experimental Psychology: Learning, Memory, \& Cognition, 20, 595607.

Elman, J. L., \& McClelland, J. L. (1984). Speech as a cognitive process: The interactive activation model. In N. Lass (Ed.), Speech and language (Vol. 10, pp. 337-374). New York: Academic Press.

Foss, D. J., \& SPEER, S. R. (1991). Global and local context effects in sentence processing. In R. R. Hoffman \& D. S. Palermo (Eds.), Cognition and the symbolic processes: Applied and ecological perspectives (pp. 115-139). Hillsdale, NJ: Erlbaum.

Frauenfelder, U. H., \& Tyler, L. K. (1987). The process of spoken word recognition: An introduction. Cognition, 25, 1-20.

FraZIER, L. (1987). Structure in auditory word recognition. Cognition, 25, 157-187.

FrAzIER, L., \& RAYNER, K. (1982). Making and correcting errors during sentence comprehension: Eye movements in the analysis of structurally ambiguous sentences. Cognitive Psychology, 14, 178-210.

FriedericI, A. D. (1985). Levels of processing and vocabulary types: Evidence from on-line comprehension in normals and agrammatics. Cognition, 19, 133-l66.

FriedERICI, A. D. (1995). The time course of syntactic activation during language processing: A model based on neuropsychological and neurophysiological data. Brain \& Language, 50, 259-281.

Friederici, A. D., Hahne, A., \& Mecklinger, A. (1996). The temporal structure of syntactic parsing: Early and late ERP effects elicited by syntactic anomalies. Journal of Experimental Psychology: Learning, Memory, \& Cognition, 22, 1-31.

Friederici, A. D., \& KilboRN, K. (1989). Temporal constraints on language processing: Syntactic priming in Broca's aphasia. Journal of Cognitive Neuroscience, 1, 262-272.

FrIedERICI, A. D., \& MECKLINGER, A. (1996). Syntactic parsing as revealed by brain responses: First-pass and second-pass parsing processes. Journal of Psycholinguistic Research, 25, 157-176.

Friedericl, A. D., Pfeifer, E., \& Hahne, A. (1993). Event-related brain potentials during natural speech processing: Effects of semantic, morphological and syntactic violations. Cognitive Brain Research, 1, 183-192.

FRIEDERICI, A. D., \& SADDY, D. (1993). Disorders of word class processing in aphasia. In G. Blanken, J. Dittmann, H. Grimm, J. C. Marshall, \& C. W. Wallesch (Eds.), Linguistic disorders and pathologies (pp. 169-181). Berlin: De Gruyter.

FRISCH, S., \& FRIEDERICI, A. D. (1998). Verb-argument structure processing: The influence of verb-specific and argument-specific constraints. Poster presented at the Eleventh Annual CUNY Conference on Human Sentence Processing, New Brunswick, NJ.

Gorrell, P. (1995). Syntax and parsing. Cambridge: Cambridge University Press.

Gunter, T. C., Stowe, L. A., \& Mulder, G. (1997). When syntax meets semantics. Psychophysiology, 34, 660-676.

Hagoort, P., Brown, C., \& Groothusen, J. (1993). The syntactic positive shift as an ERP measure of syntactic processing. Language \& Cognitive Processes, 8, 439-483.
Hahne, A., \& Friederici, A. D. (1999). Electrophysiological evidence for two steps in syntactic analysis: Early automatic and late controlled processes. Journal of Cognitive Neuroscience, 11, 193-204.

Halgren, E., \& SMith, M. E. (1987). Cognitive evoked potentials as modulatory processes in human memory formation and retrieval. Human Neurobiology, 6, 129-139.

Holcomb, P. J., \& Neville, H. (1990). Auditory and visual semantic priming in lexical decision: A comparison using event-related brain potentials. Language \& Cognitive Processes, 5, 281-312.

Hopf, J. M., Bayer, J., Bader, M., \& Meng, M. (1998). Eventrelated brain potentials and case information in syntactic ambiguities. Journal of Cognitive Neuroscience, 10, 264-280.

HUYNH, H., \& FELDT, L. A. (1970). Conditions under which square ratios in repeated measurement designs have exact F-distributions. Journal of the American Statistical Association, 65, 1582-1589.

KutAs, M. (1997). Views on how the electrical activity that the brain generates reflects the functions of different language structures. Psychophysiology, 34, 383-398.

Kutas, M., \& Hillyard, St. A. (1980). Reading senseless sentences: Brain potentials reflect semantic incongruity. Science, 207, 203-205.

Kutas, M., \& Hillyard, ST. A. (1984). Brain potentials during reading reflect word expectancy and semantic association. Nature, 307, 161-163.

Kutas, M., Lindamood, T. E., \& Hillyard, St.A. (1984). Word expectancy and event-related brain potentials during sentence processing. In S. Kornblum \& J. Requin (Eds.), Preparatory states and processes (pp. 217-238). Hillsdale, NJ: Erlbaum.

Kutas, M., \& VAN Petten, C. (1988). Event-related potential studies of language. In P. K. Ackles, J. R. Jennings, \& M. G. H. Coles (Eds.), Advances in psychophysiology (Vol. 3, pp. 139-187). Greenwich, CT: JAI Press.

LEVELT, W. J. M. (1989). Speaking: From intention to articulation. Cambridge, MA: MIT Press.

MARSLEN-WILSON, W. D. (1987). Functional parallelism in spoken word recognition. Cognition, 25, 71-102.

Marslen-WiLson, W. D. (1989). Access and integration: Projecting sound onto meaning. In W. D. Marslen-Wilson (Ed.), Lexical representation and process (Vol. 1, pp. 3-24). Cambridge, MA: MIT Press.

MARSLEN-WILSON, W. D., \& TYLER, L. K. (1980). The temporal structure of spoken language understanding. Cognition, 8, 1-71.

MCCARTHY, G., \& WOOD, C. C. (1985). Scalp distributions of eventrelated potentials: An ambiguity associated with analysis of variance models. Electroencephalography \& Clinical Neurophysiology, 62, 203-208.

MCClelland, J. L., \& Rumelhart, D. E. (1981). An interactive activation model of context effects in letter perception: Part I. An account of basic findings. Psychological Review, 88, 375-407.

MCKinnon, R., \& Osterhout, L. (1996). Constraints on movement phenomena in sentence processing: Evidence from event-related brain potentials. Language \& Cognitive Processes, 11, 495-523.

Mecklinger, A., Schriefers, H., Steinhauer, K., \& Friederici, A. D. (1995). Processing relative clauses varying on syntactic and semantic dimensions: An analysis with event-related potentials. Memory \& Cognition, 23, 477-494.

MeYer, D. M., \& Schvaneveldt, R. W. (1971). Facilitation in recognizing pairs of words: Evidence of a dependence between retrieval operations. Journal of Experimental Psychology, 90, 227-234.

Mitchell, D. C. (1989). Verb-guidance and other lexical effects in parsing. Language \& Cognitive Processes, 4, 123-154.

Münte, T. F., Heinze, H.-J., \& MANGUn, G. R. (1993). Dissociation of brain activity related to syntactic and semantic aspects of language. Journal of Cognitive Neuroscience, 5, 335-344.

Münte, T. F., MatZKe, M., \& JohanNES, S. (1997). Brain activity associated with syntactic incongruencies in words and pseudo-words. Journal of Cognitive Neuroscience, 9, 318-329.

NEELY, J. H. (1991). Semantic priming effects in visual word recognition: A selective review of current findings and theories. In D. Besner \& G. Humphreys (Eds.), Basic processes in reading: Visual word recognition (pp. 264-336). Hillsdale, NJ: Erlbaum.

NeEly, J. H., \& KeEfE, D. E. (1989). Semantic context effects on visual 
word processing: A hybrid prospective/retrospective processing theory. In G. H. Bower (Ed.), The psychology of learning and motivation: Advances in research and theory (Vol. 24, pp. 207-248). New York: Academic Press.

Neville, H.-J., Mills, D. L., \& Lawson, D. L. (1992). Fractionating language: Different neural subsystems with different sensitive periods. Cerebral Cortex, 2, 244-258.

Neville, H.-J., Nicol, J. L., Barss, A., Forster, K. I., \& Garrett, M. F. (1991). Syntactically based sentence processing classes: Evidence from event-related brain potentials. Journal of Cognitive Neuroscience, 3, 155-170.

Nobre, A. C., \& MCCARTHY, G. (1994). Language-related ERPs: Scalp distributions and modulations by word type and semantic priming. Journal of Cognitive Neuroscience, 6, 233-255.

NoRRIS, D. (1986). Word recognition. Cognition, 22, 93-136.

O'Grady, W., Dobrovolsky, M., \& Aronoff, M. (1989). Contemporary linguistics. New York: St. Martin's Press.

OLDFIELD, R. C. (1971). The assessment and analysis of handedness: The Edinburgh Inventory. Neuropsychologia, 9, 97-113.

O'Seaghdha, P. G. (1989). The dependence of lexical relatedness effects on syntactic connectedness. Journal of Experimental Psychology: Learning, Memory, \& Cognition, 15, 73-87.

O'SEAGHDHA, P. G. (1997). Conjoint and dissociable effects of syntactic and semantic context. Journal of Experimental Psychology: Learning, Memory, \& Cognition, 23, 807-828.

Osterhout, L., \& HolcomB, P. J. (1992). Event-related brain potentials elicited by syntactic anomaly. Journal of Memory \& Language, 31, 785-804.

Osterhout, L., Holcomb, P. J., \& Swinney, D. A. (1994). Brain potentials elicited by garden-path sentences: Evidence of the application of verb information during parsing. Journal of Experimental Psychology: Learning. Memory, \& Cognition, 20, 786-803.

OSTERHOUT, L., \& MOBLEY, L. A. (1995). Event-related brain potentials elicited by failure to agree. Journal of Memory \& Language, 34, 739773.

PosNer, M. I., \& SNyder, C. R. R. (1975). Attention and cognitive control. In R. L. Solso (Ed.), Information processing and cognition: The Loyola Symposium (pp. 55-85). Hillsdale, NJ: Erlbaum.

RatCLIFF, R., \& McKoon, G. (1988). A retrieval theory of priming in memory. Psychological Review, 95, 385-408.

Rayner, K., Carlson, M., \& Frazier, L. (1983). The interaction of syntax and semantics during sentence processing: Eye movements in the analysis of semantically biased sentences. Journal of Verbal Learning \& Verbal Behavior, 22, 358-374.

RAYNER, K., \& FraziER, L. (1987). Parsing temporarily ambiguous complements. Quarterly Journal of Experimental Psychology, 39A, 657-673.

Rösler, F., Friederici, A. D., Pütz, P., \& Hahne, A. (1993). Eventrelated brain potentials while encountering semantic and syntactic constraint violations. Journal of Cognitive Neuroscience, 5, 345-362.

RUGG, M. D. (1990). Event-related brain potentials dissociate repetition effects of high- and low-frequency words. Memory \& Cognition, 18, 367-379.

SChriefers, H., Friederici, A. D., \& Rose, U. (1998). Context effects in visual word recognition: Lexical relatedness and syntactic context. Memory \& Cognition, 26, 1292-1303.

Seidenberg, M. S., Waters, G. S., SANders, M., \& Langer, P. (1984). Pre- and postlexical loci of contextual effects on word recognition. Memory \& Cognition, 12, 315-328.

STANOVICH, K. E., \& WeSt, R. F. (1983). On priming by a sentence context. Journal of Experimental Psychology: General, 112, 1-36.

SWINNEY, D. A. (1979). Lexical access during sentence comprehension: (Re)consideration of context effects. Journal of Verbal Learning \& Verbal Behavior, 18, 645-659.

Tanenhaus, M. K., Carlson, G. N., \& Seidenberg, M. S. (1985). Do listeners compute linguistic representations? In D. Dowty, L. Kartunnen, \& A. Zwicky (Eds.), Natural language parsing: Psychological, theoretical, and computational perspectives (pp. 359-408). Cambridge: Cambridge University Press.
Tanenhaus, M. K., Carlson, G. N., \& Trueswell, J. C. (1989). The role of thematic structures in interpretation and parsing. Language \& Cognitive Processes, 4, 211-234.

Trueswell, J. C., Tanenhaus, M. K., \& Kello, C. (1993). Verbspecific constraints in sentence processing: Separating effects of lexical preference from garden-paths. Journal of Experimental Psychology: Learning, Memory, \& Cognition, 19, 528-553.

Van Petten, C. (1993). A comparison of lexical and sentence-level context effects in event-related potentials. Language \& Cognitive Processes, 8, 485-531.

Van Petten, C., \& Kutas, M. (1990). Interactions between sentence context and word frequency in event-related brain potentials. Memory \& Cognition, 18, 380-393.

VAn Petten, C., \& Kutas, M. (1991). Influences of semantic and syntactic context on open-closed-class words. Memory \& Cognition, 19 , 95-112.

WeSt, R. F., \& STANovich, K. E. (1986). Robust effects of syntactic structure on visual word processing. Memory \& Cognition, 14, 104112.

Wright, B., \& GARRETT, M. (1984). Lexical decision in sentences: Effects of syntactic structure. Memory \& Cognition, 12, 31-45.

ZWITSERLOOD, P. (1989). The locus of the effects of sentential-semantic context in spoken-word processing. Cognition, 32, 25-64.

\section{NOTES}

1. Note that a similar prediction does not necessarily hold for the use of other types of syntactic information such as information about a noun's syntactic gender, a verb's argument structure, or agreement information between two elements. Local phrase structure building is rather assumed to be blind with respect to gender information since the structure of a noun phrase can be built independent of this information. Some serial models are also compatible with the claim that verb argument structure information does not affect initial structure-building processes, either (e.g., Frazier \& Rayner, 1982; Rayner, Carlson, \& Frazier, 1983; Rayner \& Frazier, 1987). The latter assumption, however, has been challenged by data showing an immediate effect of argument structure on parsing (Boland, Tanenhaus, Garnsey, \& Carlson, 1995; Tanenhaus, Carlson, \& Trueswell, 1989; Trueswell, Tanenhaus, \& Kello, 1993).

2. There have been only a few reports on N400-like effects elicited by syntactic anomalies (see, e.g., Osterhout \& Holcomb, 1992; Osterhout, Holcomb, \& Swinney, 1994). However, some of these anomalies involved subcategorization violations for which an additional lexical reaccess can be assumed (Frisch \& Friederici, 1998; Hopf, Bayer, Bader, \& Meng, 1998). Or, the negativity occurred at the final word of a word string, which could be interpreted as an incomplete sentence (e.g., The broker persuaded to sell the STOCK. [... was sent to jail]; The broker hoped to sell the stock was sent to JAIL. [... and then lost all his money]; Osterhout \& Holcomb, 1992). It may well be that both lexical reaccess and processing of semantically uninterpretable incomplete sentences elicit N400-like components.

3. Note that German, unlike English, is a language with relatively free word order. This dramatically reduces the possibility of constructing definite local violations of the syntactic structure. A prepositional phrase in a sentence construction where the main verb occurs in sentence final position is one of the very few constructions that fulfill these requirements and allows testing of word category violations and semantic violations in similar sentence constructions. One consequence of the linguistic restrictions in German is that the critical word appeared in sentence final position. Thus the question arises whether the expected ERP effects could be overshadowed by sentence final wrap-up effects. In previous ERP studies, sentence final words of congruous sentences elicited a positive waveform (Van Petten \& Kutas, 1991), whereas final words of syntactically anomalous sentences were sometimes associated with a negativity (e.g., McKinnon \& Osterhout, 1996). Thus, both correlates would reduce rather than enhance the predicted P600 effects in the conditions containing syntactic violations. N400 effects due to semantic violations, on the other hand, seem generally to be very robust 
irrespective of word position. In fact, the original N400 finding was reported for sentence final positions (Kutas \& Hillyard, 1980).

4. The remaining numbers of correct trials per participant and condition contributing to the grand average thus amounted to 52.2 (correct), 58.0 (SemMM), 56.1 (SynMM), and 53.5 (Sem_SynMM), respectively.

5. Neville et al.'s (1992) open class (oc) set included nouns, verbs, and adjectives, and their closed class (cc) set included articles, prepositions, conjunctions, and so on. Nobre and McCarthy's (1994) oc set included only concrete nouns and the cc set included prepositions, conjunctions, and "articles devoid of semantic meaning." Van Petten and Kutas (1991) did not describe the word category membership constituting their oc and cc sets: "The syntactic sentences were constructed from a separate set of normal sentences by replacing each open class word by another of the same class;" this sentence was footnoted as follows: "only 'ly' adverbs were replaced; quantifiers such as 'some' and 'many' were not (see Cowart, 1982). Our dichotomous assignment of words to the open and closed class followed a similar principle of assigning words of ambiguous class to the closed class category." From this passage we may conclude that they treated "ly" adverbs like oc items and other adverbs like cc items.

6. Yet another possibility is that the difference in the $\mathrm{N} 400$ amplitude is a function of the items' frequency (mean frequency of prepositions vs. mean frequency of adverbs). Although the logarithmic frequencies for items in both categories are very high (i.e., 3.3 and 2.0, respectively), there is still a difference that might contribute to this effect (see Van Petten \& Kutas, 1990). The influence of word frequency was tested by comparing the $\mathrm{N} 400$ amplitudes for high- and low-frequency items of both categories according to the CELEX database (see Burnage, 1990). Word frequency showed neither a main effect nor a significant interaction with word category. There was only a tendency for prepositions, according to which rare prepositions counterintuitively elicited a smaller N400 than did frequent ones. Thus frequency effects per se were not very likely to account for the data pattern.

7. It might be argued that this relative syntactic positivity was due to the ongoing negativity $(\mathrm{N} 400)$ in the semantic mismatch condition and that the correct condition would serve as a more reliable control. In order to test this possibility, we also computed separate comparisons between the correct condition and each of the syntactic mismatch conditions. The differences were significant for both the pure syntactic and the double violation conditions at midline as well as lateral electrodes $(p<.05 ;$ see also Figure 3$)$.
8. Similar to the N400 effects, the syntactic P600 effect could also be confirmed using baseline-to-peak measures. Moreover, the P600 difference also reached significance for the corresponding filler conditions ( 5 vs. 7 ), again demonstrating the effect within the same experiment $[F(1,15)=4.68, p<.05]$

9 . With respect to latency and duration, this early negativity is similar to the one observed by Neville et al. (1991) for a phrase structure violation in visually presented sentences. Its distribution, however, is less lateralized. The relatively short duration of the component was confirmed by an additional statistical analysis for the subsequent $50-\mathrm{msec}$ window (i.e., between 150 and $200 \mathrm{msec}$ ). In this time interval, no further differences between syntactically correct and incorrect conditions were found $(p>.2)$.

10. As pointed out by one reviewer, yet a third interpretation of the small N400 amplitude in the double violation condition is possible in principle: Since the absence of any N 400 effect is usually interpreted to reflect smooth lexical integration, the present ERP pattern might, in principle, be interpreted in this way. This interpretation, however, is extremely unlikely given the performance data and the fact that sentences carrying the semantic mismatch alone did show an N400 effect.

11. Only local syntactic violations should therefore be expected to elicit P600 components to the extent to which this component reflects the attempt to reanalyze or repair the structure. Note that from this perspective, it seems rather unlikely that the positive slow wave in scrambled sentences as observed by Van Petten and Kutas (1991) can be taken as a series of subsequent $\mathrm{P} 600$ components.

12. For example, if the $\mathrm{P} 600$ reflects the mental process of deleting the preposition, the resulting sentence should clearly be judged as semantically incongruent (e.g., Der Priester wurde gebaut/The priest was built).

13. There has also been a very recent ERP study similarly suggesting an additivity of $\mathrm{N} 400$ and $\mathrm{P} 600$ for combined violations (AinsworthDarnell, Shulman, \& Boland, 1998). Apart from several methodological problems, such as uncontrolled lexical ambiguities and a very slow presentation rate, this study failed to realize the intended syntactic violation on the critical word of the so-called syntactically incorrect condition. (That is, the sentence beginning $J i l l$ entrusted the recipe FRIENDS . . . could be correctly continued as ... of her mother had given to her to her neighbor). An interesting conclusion to be drawn from their data, however, is that even strategies resulting from the experimental design may be sufficient to elicit P600-like effects.

APPENDIX

\begin{tabular}{cllll}
\hline Condition & & Context & Critical Word & Probe Word \\
\hline 1 & $\begin{array}{l}\text { Die Straße } \\
\text { The street }\end{array}$ & $\begin{array}{l}\text { wurde schnell } \\
\text { was quickly }\end{array}$ & $\begin{array}{l}\text { asphaltiert. } \\
\text { asphalted. }\end{array}$ & /Straße \\
Die Straße & wurde vom & asphaltiert. & /von \\
2 & The street & was by the & asphalted. & /by \\
& Der Priester & wurde sofort & asphaltiert. & /Pfarrer \\
3 & The priest & was immediately & asphalted. & /pastor \\
& Der Priester & wurde zur & asphaltiert. & /zur \\
4 & The priest & was for the & asphalted. & /for the \\
& Die Straße & wurde beim & geholt. & /beim \\
5 & The street & was by the & fetched. & /by the \\
& Die Piste & wurde vom Arbeiter & asphaltiert. & /Arbeiter \\
6 & The track & was by the worker & asphalted. & /worker \\
& Der Priester & wurde sofort & geholt. & /Die \\
7 & The priest & was immediately & fetched. & /the \\
& Die Piste & wurde zur & asphaltiert. & /zu \\
8 & The track & was for the & asphalted. & /for \\
& Der Priester & wurde schnell & geholt. & /Priester \\
& The priest & was quickly & fetched. & /priest \\
1 & Der Priester & wurde vom & geholt. & /vom \\
& & & &
\end{tabular}


Appendix (Continued)

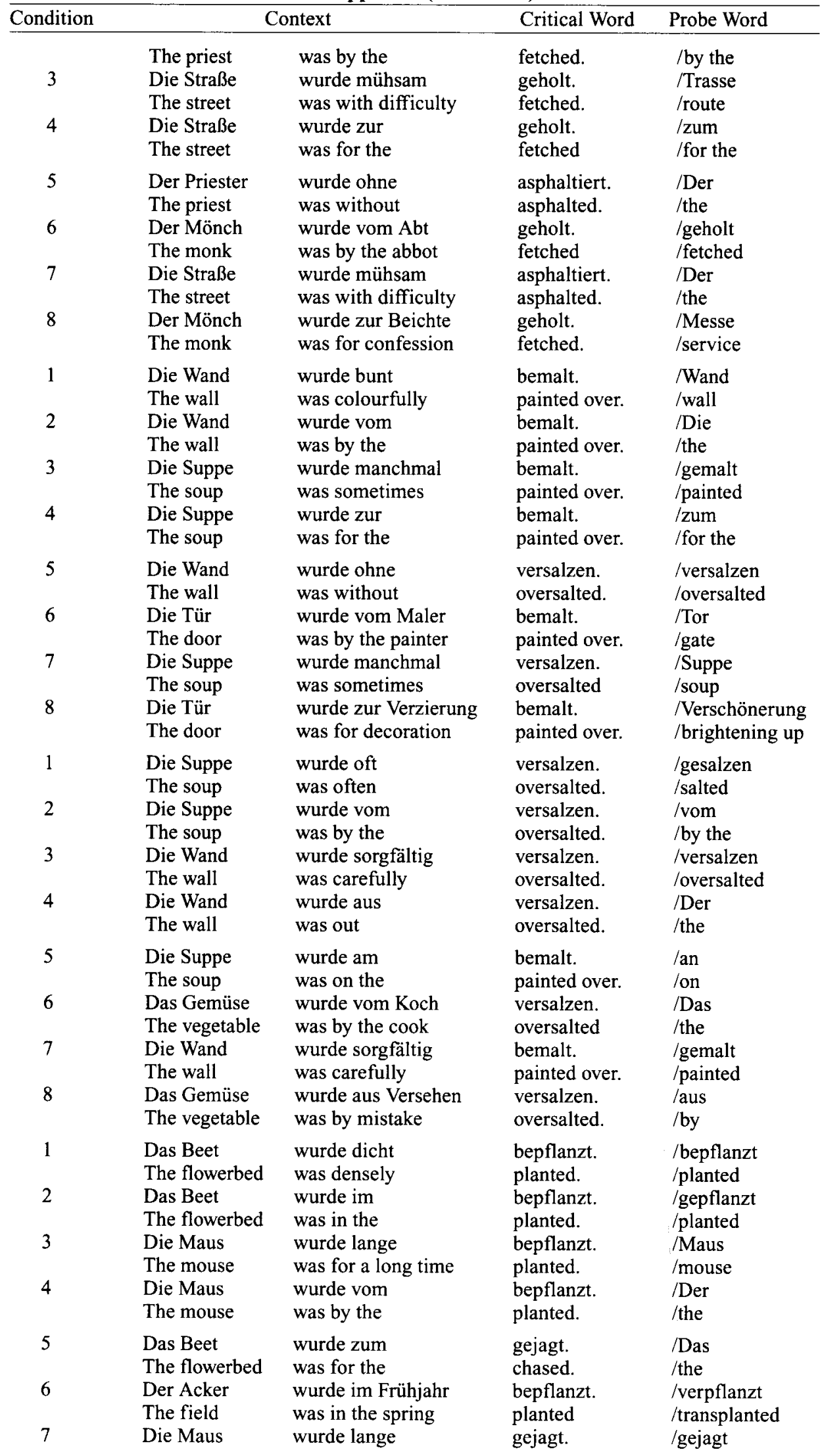


Appendix (Continued)

\begin{tabular}{|c|c|c|c|c|}
\hline \multirow{2}{*}{$\begin{array}{c}\text { Condition } \\
8\end{array}$} & \multicolumn{2}{|c|}{ Context } & \multirow{2}{*}{$\begin{array}{l}\text { Critical Word } \\
\text { chased. } \\
\text { bepflanzt. } \\
\text { planted. }\end{array}$} & \multirow{2}{*}{$\begin{array}{l}\text { Probe Word } \\
\text { /chased } \\
\text { /von } \\
\text { /by }\end{array}$} \\
\hline & $\begin{array}{l}\text { The mouse } \\
\text { Der Acker } \\
\text { The field }\end{array}$ & $\begin{array}{l}\text { was for a long time } \\
\text { wurde vom Bauern } \\
\text { was by the farmer }\end{array}$ & & \\
\hline 1 & $\begin{array}{l}\text { Die Maus } \\
\text { The mouse }\end{array}$ & $\begin{array}{l}\text { wurde ständig } \\
\text { was constantly }\end{array}$ & $\begin{array}{l}\text { gejagt. } \\
\text { chased. }\end{array}$ & $\begin{array}{l}\text { /Die } \\
\text { /the }\end{array}$ \\
\hline 2 & $\begin{array}{l}\text { Die Maus } \\
\text { The mouse }\end{array}$ & $\begin{array}{l}\text { wurde vom } \\
\text { was by the }\end{array}$ & $\begin{array}{l}\text { gejagt. } \\
\text { chased. }\end{array}$ & $\begin{array}{l}\text { /vom } \\
\text { /by the }\end{array}$ \\
\hline 3 & $\begin{array}{l}\text { Das Beet } \\
\text { The flowerbed }\end{array}$ & $\begin{array}{l}\text { wurde mühsam } \\
\text { was with difficulty }\end{array}$ & $\begin{array}{l}\text { gejagt. } \\
\text { chased }\end{array}$ & $\begin{array}{l}\text { /verjagt } \\
\text { /chased away }\end{array}$ \\
\hline 4 & $\begin{array}{l}\text { Das Beet } \\
\text { The flowerbed }\end{array}$ & $\begin{array}{l}\text { wurde als } \\
\text { was as }\end{array}$ & $\begin{array}{l}\text { gejagt. } \\
\text { chased. }\end{array}$ & $\begin{array}{l}\text { /Wiese } \\
\text { /meadow }\end{array}$ \\
\hline 5 & $\begin{array}{l}\text { Die Maus } \\
\text { The mouse }\end{array}$ & $\begin{array}{l}\text { wurde am } \\
\text { was on the }\end{array}$ & $\begin{array}{l}\text { bepflanzt. } \\
\text { planted. }\end{array}$ & /Maus \\
\hline 6 & $\begin{array}{l}\text { Das Reh } \\
\text { The deer }\end{array}$ & $\begin{array}{l}\text { wurde vom Wolf } \\
\text { was by the wolf }\end{array}$ & $\begin{array}{l}\text { gejagt. } \\
\text { chased. }\end{array}$ & $\begin{array}{l}\text { /Das } \\
\text { /the }\end{array}$ \\
\hline 7 & $\begin{array}{l}\text { Das Beet } \\
\text { The flowerbed }\end{array}$ & $\begin{array}{l}\text { wurde mühsam } \\
\text { was with difficulty }\end{array}$ & $\begin{array}{l}\text { bepflanzt. } \\
\text { planted. }\end{array}$ & $\begin{array}{l}\text { /Feld } \\
\text { /field }\end{array}$ \\
\hline 8 & $\begin{array}{l}\text { Das Reh } \\
\text { The deer }\end{array}$ & $\begin{array}{l}\text { wurde als Beute } \\
\text { was as prey }\end{array}$ & $\begin{array}{l}\text { gejagt. } \\
\text { chased. }\end{array}$ & $\begin{array}{l}\text { /aus } \\
\text { /from }\end{array}$ \\
\hline 1 & $\begin{array}{l}\text { Die Wolke } \\
\text { The cloud }\end{array}$ & $\begin{array}{l}\text { wurde schnell } \\
\text { was quickly }\end{array}$ & $\begin{array}{l}\text { durchflogen. } \\
\text { flown through. }\end{array}$ & $\begin{array}{l}\text { /umflogen } \\
\text { /flown around }\end{array}$ \\
\hline 2 & $\begin{array}{l}\text { Die Wolke } \\
\text { The cloud }\end{array}$ & $\begin{array}{l}\text { wurde vom } \\
\text { was by the }\end{array}$ & $\begin{array}{l}\text { durchflogen. } \\
\text { flown through. }\end{array}$ & $\begin{array}{l}\text { /von } \\
\text { /by }\end{array}$ \\
\hline 3 & $\begin{array}{l}\text { Die Tinte } \\
\text { The ink }\end{array}$ & $\begin{array}{l}\text { wurde häufig } \\
\text { was often }\end{array}$ & $\begin{array}{l}\text { durchflogen. } \\
\text { flown through }\end{array}$ & $\begin{array}{l}\text { /Die } \\
\text { /the }\end{array}$ \\
\hline 4 & $\begin{array}{l}\text { Die Tinte } \\
\text { The ink }\end{array}$ & $\begin{array}{l}\text { wurde trotz } \\
\text { was in spite of }\end{array}$ & $\begin{array}{l}\text { durchflogen. } \\
\text { flown through }\end{array}$ & $\begin{array}{l}\text { /Tinte } \\
\text { /ink }\end{array}$ \\
\hline 5 & $\begin{array}{l}\text { Die Wolke } \\
\text { The cloud }\end{array}$ & $\begin{array}{l}\text { wurde als } \\
\text { was as }\end{array}$ & $\begin{array}{l}\text { vergossen. } \\
\text { spilled. }\end{array}$ & $\begin{array}{l}\text { /vergossen } \\
\text { /spilled }\end{array}$ \\
\hline 6 & $\begin{array}{l}\text { Der Nebel } \\
\text { The fog }\end{array}$ & $\begin{array}{l}\text { wurde vom Piloten } \\
\text { was by the pilot }\end{array}$ & $\begin{array}{l}\text { durchflogen. } \\
\text { flown through }\end{array}$ & $\begin{array}{l}\text { /Nebel } \\
/ \text { fog }\end{array}$ \\
\hline 7 & $\begin{array}{l}\text { Die Tinte } \\
\text { The ink }\end{array}$ & $\begin{array}{l}\text { wurde häufig } \\
\text { was often }\end{array}$ & $\begin{array}{l}\text { vergossen. } \\
\text { spilled. }\end{array}$ & $\begin{array}{l}\text { /begossen } \\
\text { /watered }\end{array}$ \\
\hline 8 & $\begin{array}{l}\text { Der Nebel } \\
\text { The fog }\end{array}$ & $\begin{array}{l}\text { wurde trotz Gefahr } \\
\text { was in spite of danger }\end{array}$ & $\begin{array}{l}\text { durchflogen. } \\
\text { flown through. }\end{array}$ & $\begin{array}{l}\text { /Das } \\
\text { /the }\end{array}$ \\
\hline 1 & $\begin{array}{l}\text { Die Tinte } \\
\text { The ink }\end{array}$ & $\begin{array}{l}\text { wurde mehrmals } \\
\text { was several times }\end{array}$ & $\begin{array}{l}\text { vergossen. } \\
\text { spilled. }\end{array}$ & $\begin{array}{l}\text { /gegossen } \\
\text { /spilled }\end{array}$ \\
\hline 2 & $\begin{array}{l}\text { Die Tinte } \\
\text { The ink }\end{array}$ & $\begin{array}{l}\text { wurde vom } \\
\text { was by the }\end{array}$ & $\begin{array}{l}\text { vergossen. } \\
\text { spilled. }\end{array}$ & /vom \\
\hline 3 & $\begin{array}{l}\text { Die Wolke } \\
\text { The cloud }\end{array}$ & $\begin{array}{l}\text { wurde lange } \\
\text { was for a long time }\end{array}$ & $\begin{array}{l}\text { vèrgossen. } \\
\text { spilled. }\end{array}$ & $\begin{array}{l}\text { /Wolke } \\
\text { /cloud }\end{array}$ \\
\hline 4 & $\begin{array}{l}\text { Die Wolke } \\
\text { The cloud }\end{array}$ & $\begin{array}{l}\text { wurde beim } \\
\text { was by the }\end{array}$ & $\begin{array}{l}\text { vergossen. } \\
\text { spilled. }\end{array}$ & $\begin{array}{l}\text { /bei } \\
\text { /by }\end{array}$ \\
\hline 5 & $\begin{array}{l}\text { Die Tinte } \\
\text { The ink }\end{array}$ & $\begin{array}{l}\text { wurde im } \\
\text { was in the }\end{array}$ & $\begin{array}{l}\text { durchflogen. } \\
\text { flown through. }\end{array}$ & $\begin{array}{l}\text { /geflogen } \\
\text { /flown }\end{array}$ \\
\hline 6 & $\begin{array}{l}\text { Die Farbe } \\
\text { The colour }\end{array}$ & $\begin{array}{l}\text { wurde vom Maler } \\
\text { was by the painter }\end{array}$ & $\begin{array}{l}\text { vergossen. } \\
\text { spilled. }\end{array}$ & $\begin{array}{l}\text { /Der } \\
\text { /the }\end{array}$ \\
\hline 8 & $\begin{array}{l}\text { Die Wolke } \\
\text { The cloud } \\
\text { Die Farbe } \\
\text { The colour }\end{array}$ & $\begin{array}{l}\text { wurde lange } \\
\text { was for a long time } \\
\text { wurde beim Stolpern } \\
\text { was when stumbling }\end{array}$ & $\begin{array}{l}\text { durchflogen. } \\
\text { flown through. } \\
\text { vergossen. } \\
\text { spilled. }\end{array}$ & $\begin{array}{l}\text { /Wolke } \\
\text { /cloud } \\
\text { /vergossen } \\
\text { /spilled }\end{array}$ \\
\hline
\end{tabular}

Note-This appendix contains 8 out of 80 sentences in each of the eight conditions. Note that all sentences were translated literally, preserving German word order. The condition numbers in column 1 refer to those of Table 1. 